\title{
Economic connectivity of international transport corridor projects and the trans-Siberian railway
}

\author{
Mariia A. Khazheeva, ${ }^{1,}$, and Ekaterina A. Bondarchuk ${ }^{1}$ \\ ${ }^{1}$ Irkutsk State Transport University, 15, Chernyshevskogo str., Irkutsk, 664074, Russia
}

\begin{abstract}
The development of Russia's foreign economic potential in the current conditions of globalization is inextricably linked with the assessment of the prospects for implementing the country's transport and infrastructure potential. The importance of transport in the conditions of increasing instability of the world economy is a factor in the sustainability of the national economy. Implementing a cluster approach to the development of an efficient and modern transport and logistics infrastructure will help to accelerate the movement of goods and reduce costs in international trade, as well as the consistent integration of the country's transport system into the global network of international transport corridors. Hence, the Trans-Siberian Railway occupies a leading place in the Russian state policy on the formation of international transport corridors of latitudinal striking. The Trans-Siberian Railway's ability to provide international transit container transportation as an alternative to the traditional sea route is being considered. In this regard, consideration of the prospects for integrating the projects of international transport corridors with the participation of the Trans-Siberian Railway is most relevant. This article discusses both economic, technological and political factors that influence the potential effectiveness of this project. The prospect for the development and integration of the Trans-Siberian Railway with the Trans-Korean Railway leads to the creation of an effective transport corridor for the foreign trade of the countries of Southeast Asia and Europe, primarily the Republic of Korea with the EU countries, as well as with Russia. Analysis of the foreign trade turnover of these participants of economic cooperation shows the perspective of dynamics and the huge potential of foreign trade. Attention is focused, on the one hand, on the competitive advantages of the Trans-Siberian Railway, including an increase in throughput capacity, which is largely due to the use of the polygon management model.
\end{abstract}

Keywords: international transport corridors, Trans-Siberian Railway, transport and logistics infrastructure, container transportation

\section{Introduction}

International transport corridors (ITCs) are becoming particularly relevant in the conditions of increasing interconnectedness and interdependence. Existing as a single integrated complex, they have different transport systems of the states participating in the corridors, representing several countries with different national regulations, customs regimes and different widths of the railway track.

The Trans-Siberian Railway is the longest railway in the Russian Federation, guaranteeing direct and safe access to both Russian and transit goods from the ports of the Far East to the European Union. The modernization and development of the Trans-Siberian Railway are carried out with the active support of the state.

However, the attractiveness of rail transport is increased by the performance and capacity development capabilities of continental freight flows generated by international trade. The dynamic development of trade and economic cooperation between countries and the world's trade and economic blocs requires appropriate transport support, which can improve the increase in traffic to service regions with the global transport system and the dynamic growth of the cargo base characteristic of the countries of the Asia-Pacific region (APR) with regard to the East-West trade [5].

\section{Problem Statement}

Currently, as the trend of environmentalization increases, most coal terminals in the Baltic Sea ports are reducing transshipment due to falling demand for this type of fuel in Europe. This trend is clearly visible already as early as 2019. This adverse trend will continue in 2020. Due to the changing structure in the Baltic, a major oversupply of transshipment capacity is formed, which cannot be said about east direction. In east direction, on the contrary, there is an increase in demand for coal [7].

\footnotetext{
* Corresponding author: marya77@list.ru
} 


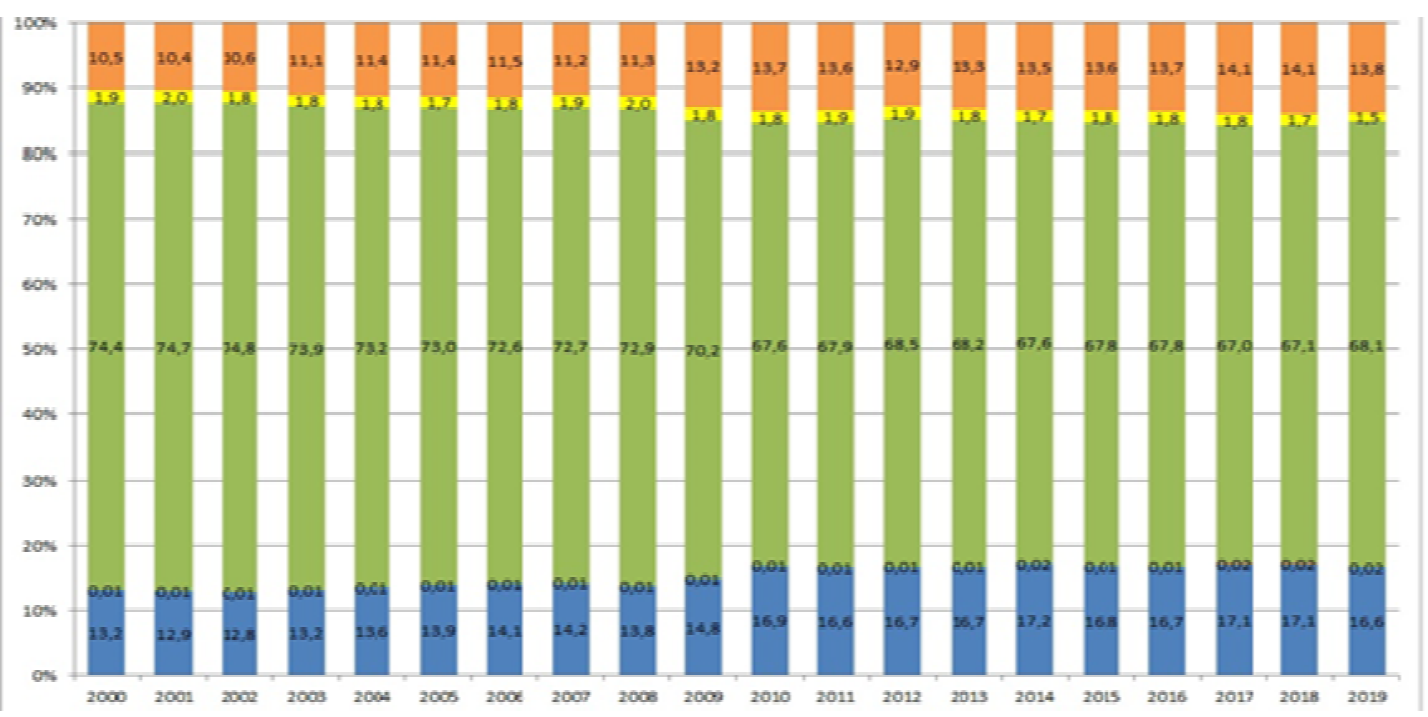

*Blue - railway; red - air; yellow - water transport; green - automobile; orange - pipeline

Figure 01. The structure of transportation by mode of transport in the Russian Federation in dynamics from 2000 to 2019 (Federal State Statistic Service, 2019)

In the "East-West" project, the basis of the Eurasian direction is the Trans-Siberian Railway, the vector of which is aimed at transport support of foreign trade relations in both Siberia and remote regions of the East and Russia as a whole.

Exploring the current economic state, we can see a slowdown in GDP growth in 2019 compared to 2018 from $2.5 \%$ to $1.3 \%$ [3]. The main reasons behind the decline in growth were: the slowdown in economic activity in the world as a whole, the maintaining and strengthening of sanctions pressure, the increase in the VAT rate, the reduction in export volumes, etc. Accordingly, we are seeing a decline in traffic across all modes of transport (Figure 1).

On the basis of the presented figure, it can be stated that over the past 19 years there has been a trend of growth in rail transport and it has been observed since 2010. But despite the growth, the leading mode of transport is still automobile transport, which occupies $68.1 \%$. However, when comparing 2019 with 2018, it can be stated that the use of railway transport has decreased by $0.5 \%$.

\section{Research Questions}

The advantages of railway transportation while implementing transit transportation are the following [12].

1. High overload of particular sections of the TransSiberian Railway.

2. The movement of main tracker trains is carried out strictly according to the schedule, which allows manufacturers and owners of goods to track and calculate the time of movement of these goods using the Internet.

3. The cargo capacity of the train is twice as high as in the EU.

The main cargo flows in this direction on the Russian railway are coal, oil, iron, ore, black metals, grain, and machines. The cargo turnover by mode of transport is represented in Table 1.

Table 01. Cargo turnover by mode of transport, 0669 (billion-t.km) [3]

\begin{tabular}{|l|c|c|c|c|c|c|c|c|}
\hline \multicolumn{1}{|c|}{ Modes of transport } & $\mathbf{2 0 0 0}$ & $\mathbf{2 0 0 5}$ & $\mathbf{2 0 1 0}$ & $\mathbf{2 0 1 5}$ & $\mathbf{2 0 1 6}$ & $\mathbf{2 0 1 7}$ & $\mathbf{2 0 1 8}$ & $\mathbf{2 0 1 9}$ \\
\hline Transport - total & $\mathbf{3 6 3 8}$ & $\mathbf{4 6 7 6}$ & $\mathbf{4 7 5 2}$ & $\mathbf{5 1 0 8}$ & $\mathbf{5 1 9 8}$ & $\mathbf{5 4 8 8}$ & $\mathbf{5 6 3 6}$ & $\mathbf{5 6 7 4}$ \\
\hline including railway transport & 1373 & 1858 & 2011 & 2306 & 2344 & 2493 & 2598 & 2602 \\
\hline automobile & 153 & 194 & 199 & 247 & 248 & 255 & 259 & 275 \\
\hline pipeline - total & 1916 & 2474 & 2382 & 2444 & 2489 & 2615 & 2668 & 2686 \\
\hline including gas pipeline & 1171 & 1317 & 1259 & 1176 & 1181 & 1300 & 1336 & 1318 \\
\hline oil pipeline & 718 & 1123 & 1084 & 1226 & 1262 & 1265 & 1276 & 1318 \\
\hline oil product pipelines & 27 & 33 & 39 & 42 & 46 & 50 & 55 & 51 \\
\hline marine & 122 & 60 & 100 & 42 & 43 & 50 & 37 & 37 \\
\hline inland water-borne & 71 & 87 & 54 & 64 & 67 & 67 & 66 & 66 \\
\hline air & 2.5 & 2.8 & 4.7 & 5.6 & 6.6 & 7.9 & 7.8 & 7.4 \\
\hline
\end{tabular}

Based on the data presented in the table, we can infer that there is an increase in freight traffic by railway transport. The largest growth was such cargo as: loading of iron ore (by 3.5 million t, or $3.0 \%$ ), of chemical and mineral fertilizers (by 1.3 million tonnes, or $2.2 \%$ ), cement (by 1.2 million tonnes, or $4.7 \%$ ), cargo in containers (by 4.1 million tonnes, or $13.1 \%$ ) [6]. In the study of the share of domestic and export 
communications, the loading structure was not transformed in 2019: 61.7 and $37.4 \%$, respectively. In loading, the main cargoes were coal, oil and construction cargoes, and ore [8].

\section{Purpose of the Study}

The aim of the research is to study and substantiate the possibilities of integration of projects of international transport corridors with the participation of the TransSiberian Railway and the use of polygon management technologies [4].

The integration of projects involves coordination between different economic entities on the same territorial plane. If there are contradictions between the entities in solving the unified issues of the connection or there are all sorts of obstacles, it all interferes with the spatial integration. Among the theoretical concepts, one of the most interesting ones, in our opinion, is the concept of the "pole of growth" by F. Perroux, according to which the economy begins to grow only in certain points, which are the "poles of growth". According to the concept of F. Perroux, the initial growth of the economy, having begun at the poles of growth, spreads and creates an "increase effect" on a national scale [13].

Another researcher, P. Pottier, considered his vision of the theory of "poles of growth", basing it on the fact that the territories among themselves are in constant cooperation, so some act as "locomotives" of growth and drag along less developed ones. This is possible due to increased cargo flows, the spread of innovation, the development of infrastructure. Therefore, the adjacent territories, located between the poles of growth, increase their level of well-being of the population through or with the aid of corridors of development, "by poles of growth - the spatial framework of economic growth of the country" [14].

The implementation of infrastructure modernization includes several stages; the initial cost of the project was 562.4 billion rubles, as a result of the audit by the Accounts Chamber of the Russian Federation was reduced to 520.5 billion rubles. The Russian Railways has already spent 30 billion rubles on the development of the Eastern Railway Polygon, but there is an "accumulate delay" [3]. However, as of 2020, the issue of financing has been practically resolved by increasing investment by 2023. The volume of investments was significantly increased by 137.5 billion by 2023 .

Intensive modernization of the Baikal-Amur Mainline and the Trans-Siberian Railway is possible only if resources are available to finance it. Therefore, the investment of the Russian Railways until 2023 will have the following indicators (Figure 2).

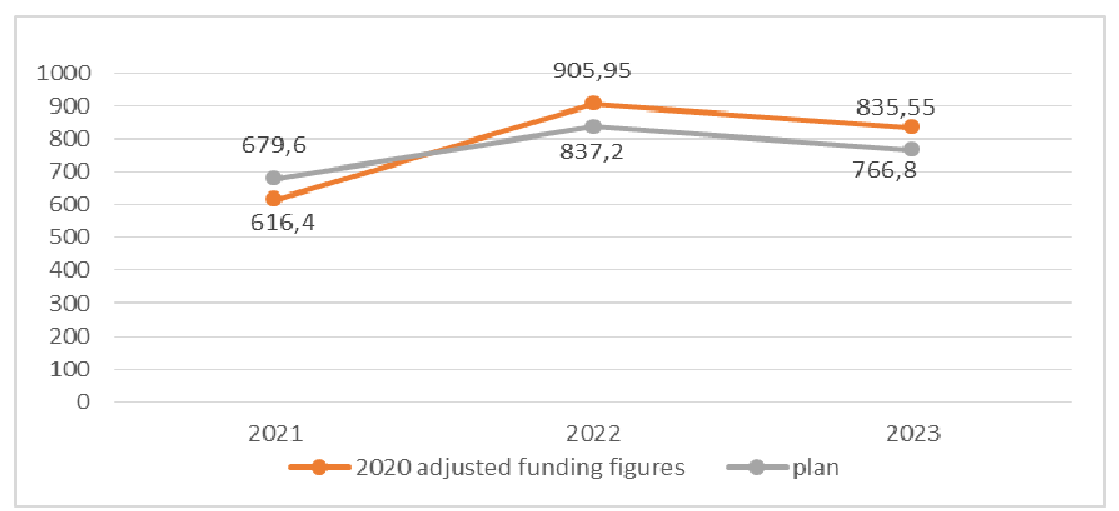

Figure 02. Adjusted financial indicators (JSC Russian railways, 2019)

To create optimal conditions for foreign trade, Russia should actively participate in the formation of the ITC. The Trans-Siberian Railway has a competitive advantage, acting as an economic bridge between the continents, both to the East and to the West. The TransSiberian Railway modernization program is expected to increase throughput capacity to more than 200 million tons of cargo per year by 2025 [11]. To achieve this result, it is necessary not only to build additional track railway lines, tunnels and junctions, but also to increase the speed of traffic, to increase the volume of transit container transportation.

\section{Research methods}

In the study, the authors used comparative analysis techniques to solve strategic management problems that require an analytical rationale [10].
It should be pointed out that the reconstruction of the Baikal-Amur Mainline and the Trans-Siberian Railway will have a positive impact not only on the growth of Russian export, but also on foreign trade traffic. The Trans-Siberian railway traffic is increasing every year, and China-Europe directions have the fastest growth dynamics. Japan also regards the Trans-Siberian Railway as the main channel for shipping goods to Europe. It is very expensive to perform transportation by plane, and shipping carries high time expenditures. Based on the proposed comprehensive infrastructure modernization plan, one can observe the dynamics of the growth of coal transportation in East direction. It is based on the Plan of export transportation of coal by railway transport in East direction (Figure 3) [11].

According to the Plan, there are two scenarios, one of which provides for the possibility of increasing coal exports to the Asia-Pacific region, both through the ports of the Far East and through the ports of South and 
Northwest directions, as well as the Arctic basin. The increased export of coal from the new coal-mining centers of the eastern regions of the country will improve the competitiveness of Russian coal in the markets of the Asia-Pacific region, by reducing transport expenditures as a result of the reduction of export shipment range [12].

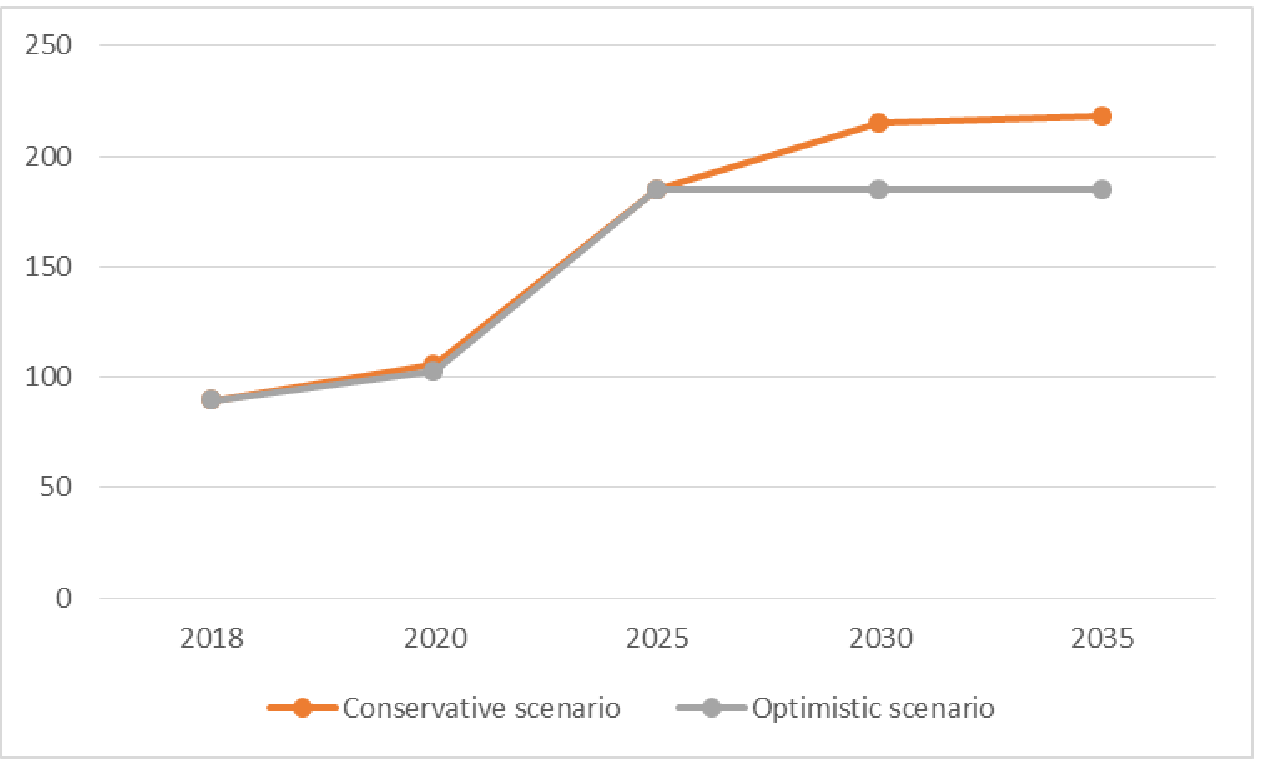

Figure 03. Coal transportation growth forecast in East direction [11]

\section{Findings}

Multi-vector development will cause high investment attractiveness of the mainline near the Polar coast, the development of raw materials of Siberia and the Far East and the development of regions. The project of connecting the Trans-Siberian and Trans-Korean mainlines (Figure 4).

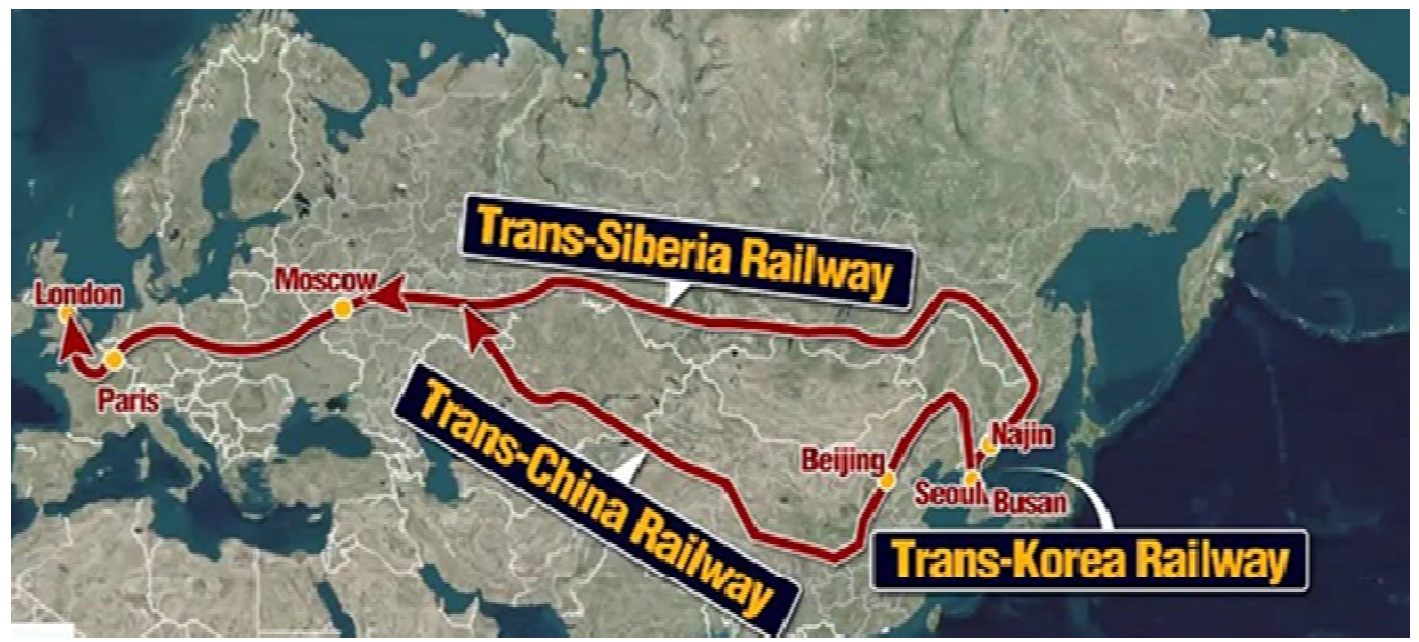

Figure 04. The variant of integration of the Trans-Siberian and Trans-Korean Railways

The junctions of the Trans-Siberian and TransKorean highways increase the load on the BaranovskyKhasan section [15]. This leads to a border crossing between Russian and Korean railways. Through it, the Trans-Siberian Railway is connected to the international transport corridor "Primorye-2", and it is one of the priority areas of reconstruction. The implementation of the Trans-Korean Railway project involves 4 accesses to the Trans-Siberian Railway. Only one of them passes through Khasan to the Trans-Siberian Railway to cross China. The other two options also represent leaving the Trans-Siberian Railway but provide transit through China and Mongolia, with West-Chita and Naushki. The fourth option includes leaving Xinjiang Uygur Autonomous Region and Kazakhstan and accessing the Trans-Siberian Railway; the Southern branch goes along the route of the Great Silk Road. This option in the railway version is called TRAKEKA (the Central Asian - Caucasian-European road) [1].

Russia's interest is outlined in Korean transit through a number of factors affecting all variants of the TransKorean rail connection to the Trans-Siberian Railway:

\section{Technological:}

- State railways and energy of the DPRK (need to restructure financing, electrical materials, etc.) The modernization of transport infrastructure involves the 
construction of a high-speed railway connecting the capitals of the two states Seoul and Pyongyang. Rajhin's advantageous position at the junction of the borders of the three states (RF, DPRK and China), being in close proximity to other dynamically developing countries (South Korea, Japan, etc.), the growth of trade and economic cooperation in the region, increasing the demand for logistics services allow one to think about the more global prospects of the project [9].

- Discrepancy between the width of the railway tracks in different countries. A modern automatic train control system has been introduced, integrated with the system of the Russian Railways OAO [10].

- Cargo base assessment. The entry of the TransSiberian Railway to the international level of transport contributes to the increase of the domestic cargo base, the development of competition in the transport sector, the implementation of a goal-oriented state policy aimed at increasing the level of quality acceptable to foreign cargo owners, as well as the speed of their implementation, the formation of long-term, profitable, stable tariff policy, understandable for counterparties, and thus, as a result, achieving stability in terms of cargo delivery.

\section{Economic:}

- Economic competitiveness of the route, especially the level of tariffs. A considerable part of goods is economically profitable to carry with the help of sea transport, as the level of tariffs is much lower. At the moment, the distribution is the following: $15 \%$ is for railway transport, the rest is for sea transport. Another reason is the technical inability to transport expensive goods by rail.

- Study of freight rail tariffs shows that there is an increase by $3.5 \%$ since January 1, 2020. Indexation of tariffs on the principle of "inflation minus." It is used from 2018 and will be in effect between now and 2025. The cumulative effect on the economy from the adjustment of tariffs for reduced inflation for the period up to 2025 will be $2.7 \%$ indexation or 41 billion rubles [12].

\section{Political:}

- Border, customs and other formalities (at the moment, there is no single automated workflow system, allowing to reduce the time for the registration of relevant transport documents).

- U.S. sanctions policy towards Russia and North Korea. The difficulties of doing business in the DPRK, due to the country's reluctance to cooperate on the basis of generally accepted economic practices and the high degree of political risks associated with the remaining military and political tensions of inter-Korean relations, deter potential investors willing to pour cash in the development of the project.

The above-mentioned groups of factors influence the effectiveness of the planned project to a different extent. Taken together, they will provide a comprehensive look at the project and its implementation prospects, which in turn can be viewed from both positive and negative sides [15].

The main drawbacks are the extremely high cost of the project and the difficulty in finding sources of financing. As noted, for the time being a Russian company has invested heavily in the reconstruction of the railway infrastructure of the DPRK. However, the modernization of North Korea's railways, the resumption of direct trans-Korean railway communication, with access to the mainline, can be a huge burden for any country [16].

Among the prospective consequences of the project, it is advisable to highlight:

\section{- access to the non-freezing port.}

One of the huge advantages in the future is the obtaining of another non-freezing port of Rajhin for the Russian Federation at the current operating capacity 5 million tons annually. Currently, the mediator is the People's Republic of China. Coal from the Far East goes to China by rail through the border crossings of Makhalino-Hunchun and Grodekovo-Suifenhe, the volume of transshipment is comparable to the volumes going through Rajhin [3].

\section{- increased economic security.}

The development of mutually beneficial cooperation will return dividends not only to both Koreas, but will help to reduce tension in this part of the world, which has a positive effect for Russia as well. Among other things, this project retains Russia as an influential player on the Korean peninsula. In the case of the DPRK, the North Korean side has received a ready-made infrastructure project on its territory. The cooperation has created job opportunities and also allows North Korea to make profits with port fees [13].

Some of the negative effects are expected to be leveled by increasing throughput capacity, including the Trans-Siberian line. Improving the speed of transportation of raw materials through it, domestic and foreign, following in transit from the superpowers of the Asia-Pacific region to Europe is one of the priorities for today. To a great extent, this is facilitated by the application of the polygon management model.

In 2019, a new, unified traffic management directorate was created. A single technological space in the entire direction of the cargo flow from Kuzbass to the seaports of the Far East will contribute to the transportation process efficiency on the basis of the polygon management model. So far, the new structure has included two directorates - East Siberian and TransBaikalian. In the long run, the functions and staff numbers of the Krasnoyarsk and Far Eastern directorates of the traffic management will be transferred under its authority. The new centre allows the management of operational and technological communication systems within the borders of the Eastern Polygon site. The centralization of the management of communication systems and their smooth operation will have a positive impact on the East Siberian mainline's task performance on the increase of the cargo flows through the TransSiberian Mainline and the Baikal-Amur Mainline. Work in the conditions of the polygon management model allowed the East Siberian Railway to increase the service speed from $44 \mathrm{~km} / \mathrm{h}$ in 2016 to $45.1 \mathrm{~km} / \mathrm{h}$ in 2018 , the journey speed of delivery of all shipments by $44.8 \mathrm{~km} /$ day; the overall reliability of delivery increased by $3.1 \%$. 


\section{Conclusion}

Summarizing the above, we can say with confidence that this integration is very beneficial in a long term for both Russia and the DPRK. The development of transport corridors will contribute to the growth of the level and quality of the population's well-being, strengthening geopolitical, infrastructure, economic positions on the entire route of the transport corridor [14]. Therefore, the formation of the transport complex of the world economic system is manifested in its dynamic development. Gradual development and modernization of the existing infrastructure subsequently open huge sales markets for domestic companies abroad.

\section{Acknowledgments}

Published at the expense of the state task on the topic "Improving the mechanisms of interaction between polygon structures and regional corporate governance centers by the example of the Eastern railway polygon".

\section{References}

1. V.A. Batyr. The Hasan-Rajin Russian and North Korean Project in the System of International Economic Constraints (Impregnable RussianChinese Bastion in the DPRK). Lex Russica, 4(137), 53-69 (2018)

2. Y.Y. Eglit, O.Y. Ogaltcova, A.V. Andorskaya, M.A. Shapovalova. Digitalization of container transportation and its impact on logistics. Syst. Anal. and logist., 4(22), 40-46 (2019)

3. Cargo turnover by mode of transport in the Russian Federation (2019) Fed. State Stat. Service. Retrieved from: https://rosstat.gov.ru/folder/23455?print=1

4. Modernization of the Baikal-Amur Mainline and the Trans-Siberian Railway (2018) Interfax. Retrieved from: https://rzdfuture.interfax.ru/transsib/

5. Cargo and rail tariffs rose by $3.5 \%$ from 0101 (2020) Interfax. Retrieved from: https://company.rzd.ru/ru/9401/page/78314?id=183 368

6. The Annual Report of the Russian Railways OAO over 2019 (2019) JSC Russian railways. Retrieved from: https://ar2019.rzd.ru/ru/performanceoverview/market-overview

7. M.A. Khazeeva, E.A. Belobrova. Current state of railway transport in Russia. Econ. and Entrepr., 6(107), 101-106 (2019)

8. N. Kucherov. The Baikal-Amur Mainline and the Trans-Siberian Railway upgrades will pay off in spades, 4 (2019). Retrieved from: https://www.ritmeurasia.org/news

9. The plan of the export transportation of coal by rail in East direction (2020) Ministry of energy. Retrieved from:
10. "Eternal fix income securities" have been found for the Baikal-Amur Mainline and the Trans-Siberian Railway (2020) Nezavisimaya Gazeta. Retrieved from: https://company.rzd.ru/ru/9401/page/ 78314 ? id=191616

11. Strategy for the development of service exports until 2025 (2019) Order of the Government of the Rus. Fed., no. 1797-r. Retrieved from: https://www.economy.gov.ru/material/file/6a532b02 91a562e597a55aa491061df7/strategiya.pdf

12. O. Perepelitsa. From the Trans-Siberian Railway to the Eurasian Corridor (2013). Retrieved from: http://magazines. russ.ru/oz/2013/3/22p.html

13. F.L'. Perroux. Economie du XXe siècle (Paris, 1961)

14. P. Pottier. Axes de communication et développement économique. Rev. écon. 14, 58-132 (1963)

15. Russian-North Korean logistics project "KhasanRajhin": Current state and prospects for development in new conditions (2018) RASONCONTRANS. Retrieved from: http://rasoncontrans.com/images/files/Lprojectru.pdf

16. Russian Railways in numbers (2019). Retrieved from: https://oldwww.rzd.ru/static/public/ru?STRUCTURE_ID=523 2\&layer_id=3290\&refererLayerId=162\&id=4085 